\title{
Biofuel Utilization and Implications in ASEAN Based on Case Analysis of Developed Countries ${ }^{1}$ (ap
}

\author{
Su Jung $\mathrm{Heo}^{2} \cdot$ Joon Weon Choi $\mathbb{1}^{2,3, \dagger}$
}

\begin{abstract}
ASEAN countries consist of vast coastal areas and thousands of islands that are vulnerable to the effects of climate change on sea level rise. It is believed that this will play an important role in reducing greenhouse gas emissions globally in order to minimize the damage suffered by ASEAN countries. To overcome this issue, biofuels have been used to minimize the impact on the environment by replacing fossil fuels and to reduce greenhouse gas emissions. In those cases of United States, Brazil and Europe, where biofuels are highly utilized, research, development and investment in this field have been actively conducted in the past. In ASEAN countries, however, it has not been a long time since the biofuel policies were established. To overcome this problem, we investigated the renewable fuel policy in the United States, Brazil and the European Union. Based on this, we suggested the utilization plan and prospect of biofuel policy in ASEAN countries.
\end{abstract}

Keywords: ASEAN, biofuel, sustainable policy, energy security, Renewable Energy Directive, Renewable Fuel Standard

\section{INTRODUCTION}

Sea level rise caused by global warming and environmental problems such as increased harmful substances have become global issues, and development and utilization of renewable energy can be said to be a task to be solved by all countries. As a result, research on renewable energy which can replace fossil fuels worldwide has been spotlighted. Typical expected benefits obtained by using biofuels include mitigation of climate change, improvement of energy security and job creation in rural areas.

Corn produced through fermentation in the United States (U.S.), bioethanol derived from sugarcane in Brazil, and biodiesel produced from oil seed ${ }^{1)}$ through alkyl esterification in the European Union (EU) are typical biofuels. As such, biofuel is used as practical alternative fuel but ASEAN $^{2)}$ countries are far from how the U.S. and the EU which are taking active policies to use biomass. ${ }^{3)}$ Although it is difficult to apply the same level of policies of the developed countries, effective biofuel policies are expected to be implemented

1 Date Received June 28, 2018, Date Accepted September 11, 2018

${ }^{2}$ Graduate School of International Agricultural Technology, Seoul National University, Pyeongchang, Gangwon-do 25354, Republic of Korea

3 Institute of Green-Bio Science and Technology, Seoul National University, Pyeongchang, Gangwon-do 25354, Republic of Korea

† Corresponding author: Joon Weon Choi (e-mail: cjw@snu.ac.kr, ORCID: 0000-0002-9454-0475) 
through the cases. In the previous study, the author examined the use and prospect of Lignocellulosic bioethanol in ASEAN countries (Heo and Choi, 2017). However, it was confirmed that there are limitations to enforcement of policies due to technical limits. Thus, this study is conducted to find a method for complementing this. The current size and status of the cellulosic bioethanol market are very limited to replace targets of each country (Kim, 2016). Although there is a case of applying to the domestic situation by analyzing the precedent set by the developed countries (Cho and Lee, 2013; Park, 2011), this study has a different significance because it is based on the situation of ASEAN countries. This study looked at Renewable Fuel Standard and biofuel supply policies of the U.S. and Brazil which are based on bioethanol, and the EU which is based on biodiesel. The policy background and plan of Renewable Fuel Standard (RFS) and Renewable Energy Directives (RED) are set out and the utilization methods of biofuel in the U.S., Brazil and Europe are analyzed as overseas cases. The current biofuel policies adopted in ASEAN countries are investigated. Based on this, implications on policies of ASEAN countries, which need to be improved at this stage, are explored through the related cases of the developed countries.

\section{MATERIALS and METHODS}

\subsection{RFS}

RFS was enacted by the Energy Policy $\mathrm{Act}^{4)}$ in the U.S. in 2005 and the scope was expanded by the EISA ${ }^{5}$ in 2007. This was firstly enforced to impose the biofuel

1) Oil Seed - Seed that becomes the ingredient of oil such as soybean, sesame, cottonseed, peanut, etc.

2) Association of South-East Asian Nations

3) Typical raw material including agricultural and forestry crops and urban solid wastes
Renewable Fuel Standard on the transportation industry within the U.S., and biofuel used here includes bioethanol and biodiesel of the first and second generations (Bracmort, 2015). The main contents of RFS I are suggest the Renewable Fuel Standard and include the tracking system based on RIN $^{6}$ ) and general exemption provision for business management (Cho and Lee, 2013). According to $\mathrm{DOE}^{7}$, the person of obligation can meet the Renewable volume obligations ${ }^{8}$ by selling the required amount of biofuel or purchasing RIN from a person that exceeds the requirement. Thus, the company must own RIN that corresponds to the calculated biofuel. If not, a maximum of 32,500 USD is imposed per day (Cho and Lee, 2013).

However, there are cases of reducing the amount as they cannot meet the RFS I target and RFS II appeared in 2010 to complement RFS 1 (2007). Unlike RFS I, it defined the types of biofuel in details and suggested the practical Renewable Fuel Standard target (Bracmort, 2015). Biofuel defined by DOE must meet the minimum target of life cycle ${ }^{9)}$ GHG emission reduction compared to petroleum and the criteria are as follows: 1) Biofuel of the first generation ${ }^{10)}$ - reduce by more than $20 \%$ in life cycle of GHG; 2) Advanced ${ }^{11)}$ biofuel - i. Biodiesel - reduce by more than $50 \%$, ii. Cellulosic biofuel - reduce by more than $60 \%$. The U.S. Energy Environmental Protection Agency (EPA) manages the RFS program and sets the amount based on the EISA

4) Energy Policy Act

5) Energy Independence and Security Act

6) Renewable Identification Numbers

7) Department of Energy

8) RVOs - Renewable volume obligations

9) Life Cycle GHG emissions

10) First generation: Grain-based biomass that compete with food including corn and sugarcrane.

11) Advanced biofuel: Cellulosic/microalgae-based biomass that do not compete with food; renewable fuel other than ethanol extracted from cornstarch with less than $50 \%$ of life cycle GHG emission. 


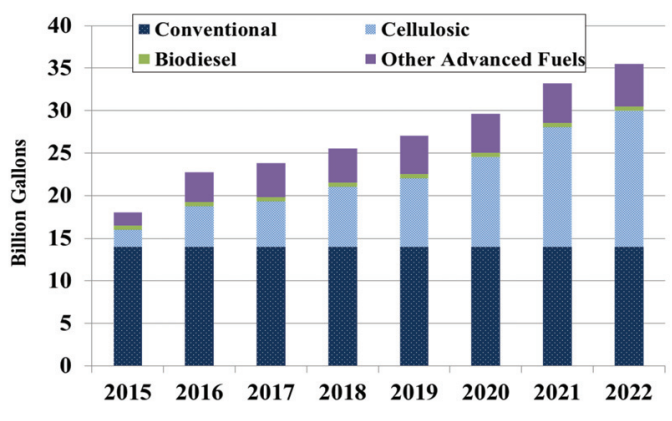

Fig. 1. Renewable fuel standard volumes by year (DOE, 2017).

law and requirements for the amount of each category in accordance with fuel availability (DOE, 2017). In general, $\mathrm{EPA}^{12)}$ evaluates based on the information such as individual production plan and progression speed, which is obtained through discussion with each producer, EIA ${ }^{13)}$, USDA ${ }^{14)}$ and $\mathrm{DOE}^{15)}$ to determine the amount to be imposed on Renewable Fuel Standard volumes of cellulosic biofuel (Bracmort, 2015). Fig. 1 anticipates Renewable Fuel standard volumes that generally increased by year. It shows that cellulosic biofuel and advanced biofuels are increasing compared to the first generation (conventional) biofuel and biodiesel that are at a constant rate.

\subsection{RED}

The EU enacted Renewable Energy Directives (RED) in 2009 and the objectives are set differently by country or region. REDs are guidelines to reduce GHG emission and dependence on fossil fuels by imposing the minimum standard for use of biofuels such as bioethanol and biodiesel (Dixon et al., 2016). The EU Commission $^{16)}$ set up a goal of reducing GHG by $6 \%$

12) Environmental Protection Agency

13) Energy Information Administration

14) United States Department of Agriculture

15) Department of Energy

16) EU Commission by increasing biofuel in the transportation industry up to 10\% until 2020 (Dixon et al., 2016; EU Commission, 2018). In addition, the objective was set in 2016 to meet the minimum $30 \%$ of the overall energy required in the field of renewable energy by 2030, but each country has a different goal such as $10 \%$ for Malta and $49 \%$ for Sweden. One year later, in December 2017, downward adjustment on renewable energy was made to $27 \%$ and EU countries can reset their national objectives based on the 2-year performance through this goal (Council of the EU, 2017). REDs not only help EU countries and other countries to meet the renewable energy objectives through cooperation but suggest the sustainability requirements to produce all biofuels produced or consumed in the $\mathrm{EU}$ in a sustainable and eco-friendly way. For instance, the minimum share of advanced biofuels is expected to be increased gradually from $0.5 \%$ in 2021 to more than $3.6 \%$ in 2030, and agricultural biomass used here must meet the following criteria: (1) To have a high biodiversity value; and (2) To be produced based on the raw material that is grown in soil with low carbon deposition (Council of the EU, 2017). Companies that produce biofuels can prove the compliance status through these sustainability criteria or voluntary plans approved by the EU Commission. Biofuels here are mostly based on the first generation (conventional) biomass, and RED II was enacted in 2016 to complement this. It targets $6.8 \%$ fuel blending by 2030 , and it is based on advanced biofuels that exclude the first generation (conventional) fuels unlike the existing RED (EU Commission, 2018). The obligation of life cycle GHG emission reduction for fuel suppliers was added to the existing RED and the detailed criteria on which cases are to be included in GHG emission were set. These criteria include 1) nitrogen dioxide emission from soil during farming; 2) emission during extraction of vegetable oil; and 3) emission during transportation and distribution of final fuel. 


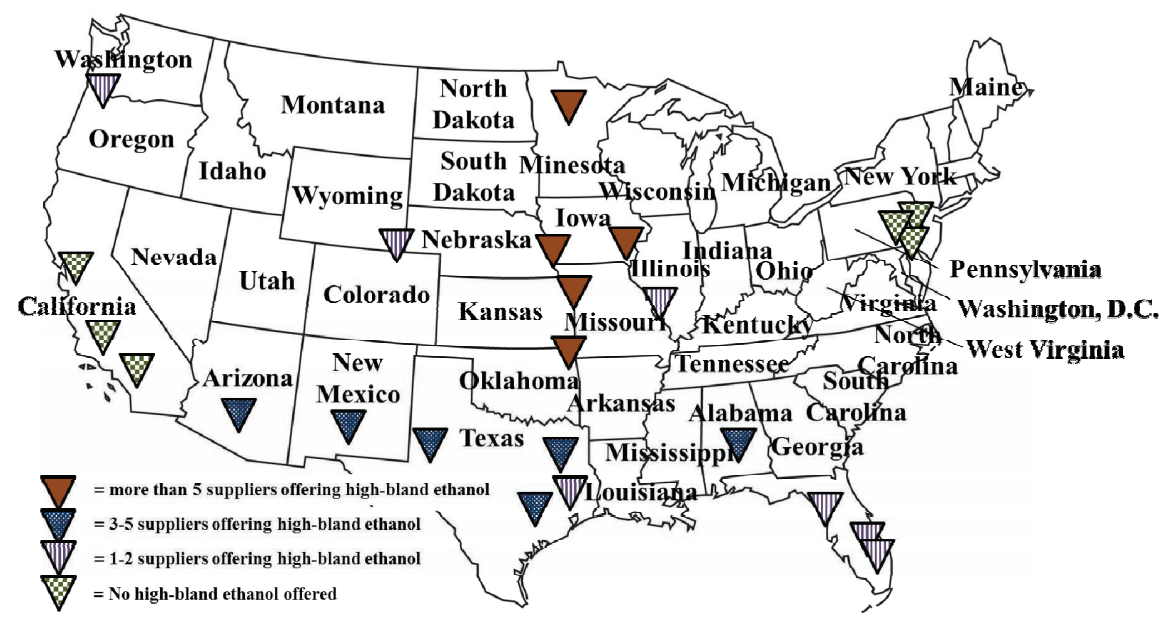

Fig. 2. Number of suppliers of bioethanol blending obligations in the U.S. (major cities only) (Modified, Stock, 2017).

\section{RESULTS and DISCUSSION}

\subsection{Biofuel cases of developed countries}

\subsubsection{U.S}

The U.S. produces nearly half of global ethanol, which is mostly produced using corn as a raw material. Ethanol production consumed 107 million tons of corn in 2009 and 112 million tons in 2010, corresponding to about one-third of overall corn production in the U.S. and 13\% of global production (Goto, 2012).

EPA is currently considering to change E10 ${ }^{17)}$ into E15 and enforces a strong policy in the field of biofuel to improve energy security (Park, 2011). It has recently been paying attention to advanced biofuel. Oklahoma is encouraging the abolition of the system that deducts 45 cents of tax per one gallon of corn-based bioethanol in gasoline (Park, 2011). According to Goto (2012), the U.S. has been offering tax reduction for federal taxes on gasoline with bioethanol content of $10 \%$ or above since 1978. Various affirmative actions related

17) E00: $00 \%$ ratio of bioethanol in gasoline to biofuel have been implemented, such as tax credit in 2004 for ethanol facilities at gas stations. Looking at different states, Illinois and 10 other states offer tax reduction for sales tax on gasoline and Minnesota and 17 other states provide subsidies to bioethanol providers (Goto, 2012). Fig. 2 indicates locations of bioethanol suppliers that meet Renewable Fuel Standard in major cities of the U.S. Suppliers that produce high-blend fuel are placed in the Gulf and the Midwest. EISA set a goal to increase from 42 billion liters (1.1 billion gallons) in 2009 to maximum of 136 billion liters (36 billion gallons) by 2022 (APEC, 2015). However, such goal comes with a clause that the goal can be lowered if the cost is too high or biofuel supply is insufficient. For instance, as EPA failed to reach 22.25 billion gallons/year planned by the U.S. Congress in 2007, the goal was lowered to produce 18 billion gallons/year of bioethanol by 2016 and 15 billion gallons/year by 2022 (APEC, 2015; APEC, 2016).

\subsubsection{Brazil}

Brazil enacted the National Alcohol Program in 1975 to reduce its dependence on import of fossil fuel, which 


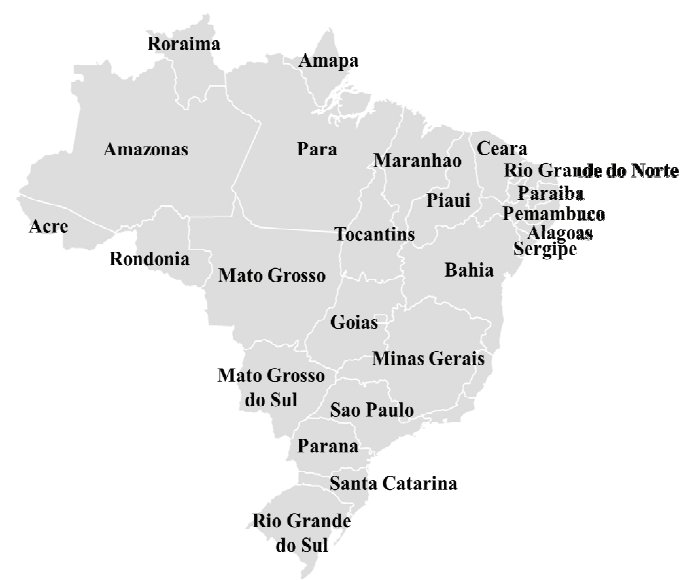

Fig. 3. Division by states in Brazil.

was increased by the first oil crisis in 1973. Due to low availability of bioethanol, the original target of E25 was not satisfied and the actual ratio was dropped to E20 in 2011. E25 was recovered in June 2012 and Renewable Fuel Standard was increased to E27 in 2015 (USDA, 2017). Actual consumption of bioethanol is higher than the standard because pure ethanol is not only used for gasoline blending but also on vehicles like FFV ${ }^{18)}$ (Brazil biofuels, 2016). Bioethanol in Brazil is mostly produced using sugarcane cultivated domestically. Sugarcane production was increased by nearly 1.7 times in 6 years, from about 396 million tons in 2003 to about 671.39 million tons in 2009 (Goto, 2012). Starting in December 2004, Brazil implemented the National Program for the Production and Use of Biodiesel (PNPB) ${ }^{19)}$ to increase national production of biodiesel (Brazil biofuels, 2016). The objective of this program is to require legal, administrative and normative measures, define a federal tax model for biodiesel, and establish the conditions for registering producers and

18) Flexible Fuel Vehicle: A dual fuel vehicle that can use both bioethanol and gasoline

19) Programa Nacional de Produção e uso do Biodiesel, PNPB
Table 1. ICMS in Brazilian states (Tax incentives) (USDA, 2017)

\begin{tabular}{|c|c|c|c|}
\hline States & & Gasoline & Bioethanol \\
\hline Acre & AC & 25 & 25 \\
\hline Alagoas & $\mathrm{AL}$ & 29 & 25 \\
\hline Amazonas & $\mathrm{AM}$ & 27 & 27 \\
\hline Amapa & AP & 25 & 25 \\
\hline Bahia & BA & 28 & 20 \\
\hline Ceara & CE & 29 & 25 \\
\hline Distrito Federal & DF & 28 & 28 \\
\hline Espirito Santo & ES & 27 & 27 \\
\hline Goias & GO & 30 & 22 \\
\hline Maranhao & MA & 28 & 26 \\
\hline Minas Gerais & MG & 29 & 14 \\
\hline Mato Grosso Sul & MS & 25 & 25 \\
\hline Mato Grosso & MT & 25 & 25 \\
\hline Para & PA & 28 & 25 \\
\hline Paraiba & PB & 29 & 23 \\
\hline Pernambuco & $\mathrm{PE}$ & 29 & 23 \\
\hline Piaui & PI & 27 & 19 \\
\hline Parana & PR & 29 & 18 \\
\hline Rio de Janeiro & RJ & 34 & 25 \\
\hline Rio Grande Norte & $\mathrm{RN}$ & 29 & 23 \\
\hline Rondonia & RO & 26 & 26 \\
\hline Rio Grande do Sul & RS & 30 & 30 \\
\hline Santa Catarina & SC & 25 & 25 \\
\hline Sergipe & $\mathrm{SE}$ & 29 & 27 \\
\hline Sao Paulo & SP & 25 & 12 \\
\hline Tocantins & TO & 29 & 29 \\
\hline
\end{tabular}

importers. According to USDA (2017), the National Council on Energy Policy (CNPE) ${ }^{20)}$ demanded gradual increase of Renewable Fuel Standard from B8 ${ }^{21)}$ in 2017 to B9 in 2018 and B10-B15 in 2019. In fact, USDA (2017) reported that bioethanol standard of the U.S. remained unchanged at E27 but biodiesel standard was increased to B8 in 2017. Bean-based biodiesel, the most

20) Conselho Nacional de Politica Energética, CNPE

21) B00: $00 \%$ ratio of biodiesel in diesel 
common type of biodiesel fuel in Brazil, was evaluated to reduce GHG emissions by $57 \%$ and $31 \%$, respectively for RFS II and RED (Directives, 2009). However, there is no separate standard for environmental sustainability of the biofuel policy of Brazil. For example, GHG reduction level and indirect land use are not taken into consideration (Brazil biofuels, 2016). Sugarcane-based ethanol produced in Brazil was evaluated to contribute to $61 \%$ of GHG reduction based on RFS II of EPA. According to the RED standard of the EU, sugarcane-based ethanol has a reduction effect of about 71\% (Directives, 2009). Fig. 2 shows the division of states in Brazil. Table 1 presents ICMS ${ }^{22}$ in each state of Brazil set by the Ministry of Planning as of July 2017. ICMS imposed on bioethanol ranges from $12 \%$ to $30 \%$ and ICMS on gasoline is $17 \sim 34 \%$. In general, ICMS is the same for bioethanol and gasoline or higher for gasoline. This implies that there is a tax benefit for production of biofuel.

\subsubsection{EU}

The EU consumed about 16.8 million tons of oilseeds such as rapeseed and sunflower to produce biodiesel in 2010, and this corresponds to about $70 \%$ of all oilseeds (Goto, 2012). In the transportation sector of the EU, biofuel accounted for about $4 \%$ of total fuel consumption from 2009 to 2013. Biodiesel takes up $75 \%$ of biofuel consumption among them (Boutesteijn et al., 2017).

Through RED, the EU recently set a target to use renewable energy sources for $20 \%$ of energy consumption and $10 \%$ of total transportation fuel by 2020. The bioenergy sector (biofuel and biomass) is expected to make contributions (Frank et al., 2013). Each EU country has different resources available and a unique energy market. This means that each country has its own target to comply with RED. The 'EAP23)'

22) Tax for Circulation of Goods and Services
Table 2. Blend rate mandate in some EU Countries (Cho and Lee, 2013, modified)

\begin{tabular}{ccc}
\hline Country & Bioethanol & Biodiesel \\
\hline \hline Germany & E2.8 & B4.4 \\
Austria & E6.1 & B6.3 \\
Romania & E7 & B7 \\
Spain & E4.1 & B7 \\
Denmark & E1 & B1 \\
Hungary & E3.1 & B4.4 \\
Greece & - & B6.5 \\
\hline
\end{tabular}

for 2020 agreed among leaders of Europe in 2007 required to increase the use of biofuel for transportation in Europe from 5.75\% in 2010 to 10\% in 2020 (Cho and Lee, 2013). The EU Commission announced a proposal to achieve minimum renewable energy rate of $27 \%$ in final energy consumption of the EU by 2030 . The current RED level varies from below 10\% of Malta to $49 \%$ of Sweden. Each country writes a biennial report on the progress.

As shown in Table 2, some EU countries are implementing Renewable Fuel Standard for biofuel. Ethanol blend rate was highest in Romania, followed by Austria and Spain. Diesel blend rate was highest in Romania and Spain, followed by Greece and Austria.

In Germany, the Biofuel Quota Law ${ }^{24)}$ was enforced to oblige 6.25\% of use until 2014 (Park, 2011). There are two main methods of budget support. First is to provide tax deduction or subsidy benefit. Second is to apply regulations like Renewable Fuel Standard to guarantee minimum market share of biofuel and minimize the financial burden of the government (Cho and Lee, 2013). In addition, the Renewable Transport Fuels Obligation ${ }^{25)}$ was promoted in the UK since April 2008 as a measure to implement the bioenergy policy

23) Energy Action Plan

24) Biofuel Quota Law

25) Renewable Transport Fuels Obligation, RTFO 
Biofuel Utilization and Implications in ASEAN Based on Case Analysis of Developed Countries

Table 3. Biofuels policy frameworks in some ASEAN countries (APEC, 2016)

\begin{tabular}{|c|c|c|c|c|c|}
\hline & \multicolumn{2}{|c|}{ Blend rate mandate } & \multicolumn{2}{|c|}{ Blend rate target } & \multirow{2}{*}{$\begin{array}{c}\text { Incentives, subsidies, } \\
\text { and taxation }\end{array}$} \\
\hline & Bioethanol & Biodiesel & Bioethanol & Biodiesel & \\
\hline Indonesia & E3 & B10 & E20(2025) & B30(2025) & $\sqrt{ }$ \\
\hline Malaysia & - & B7 & - & B10 & $\sqrt{ }$ \\
\hline Philippines & E10 & B2 & E20(2020) & B20(2025) & $\sqrt{ }$ \\
\hline Thailand & - & B7 & E30 & B20 & $\sqrt{ }$ \\
\hline Viet Nam & E5 & - & E10(2017) & - & $\sqrt{ }$ \\
\hline
\end{tabular}

statement of the EU. This obligation required gasoline and diesel sold in the UK to blend at least $2.5 \%$ of biodiesel and set a target to replace $5.26 \%$ of transport fuel with biofuel by 2013 (Park, 2011).

\subsection{Biofuel policy in ASEAN}

Renewable energy resources are rich in Southeast Asia. As a representative case, Indonesia takes up the largest part of the global palm oil industry. Indonesia devised a plan for Renewable Fuel Standard of B30 by 2025, and Malaysia the second largest country in the palm oil industry recently announced that its target will be increased from B7 to B10 (APEC, 2016; IEA 2017). Table 3 summarizes Renewable Fuel Standard and targets of some ASEAN countries. Indonesia and the Philippines set a target to increase bioethanol blend rate to E20. As for biodiesel blend rate, the target rate is B30 in Indonesia and B20 in the Philippines. Thailand set the target rate as E30 and B20. In addition, most of ASEAN countries are recently providing a biofuel policy mechanism through financing of R\&D, subsidy and tax incentive to increase competitiveness of biofuel.

\subsubsection{Indonesia}

Indonesia, a country that takes up about $40 \%$ of the global palm oil industry for sustainable production, introduced an international certification system for tenant farmers in 2015 (IEA 2017). This system introduces a more environment-friendly method of increasing productivity. In 2008, Indonesia passed Ministerial Regulation No. 32/2008 on biofuel supply, utilization and trading as a law so that biofuel can be used like other fuels (APEC, 2015). This law allows for obligation of biofuel consumption since 2009 and regulates the following matters: 1) classification of biofuel; 2) quality standard and specification; 3) pricing; 4) instruction and supervision; and 5) sanction (APEC, 2015). Biodiesel production of Indonesia was only about 190 million liters (50 million gallons) in 2009 but increased rapidly to 2,961 million liters (780 million gallons) in 2014. The number of bio-refinery ${ }^{26)}$ plants was increased from 7 to 26 (USDA, 2015). According to IRENA (2017a), Renewable Fuel Standard of Indonesia was increased from B10 to B15 in 2015. The Estate Fund Agency for palm oil estate was newly launched to cover production of palm oil. Biodiesel produced in Indonesia is mostly based on palm oil, and total area of palm oil cultivation is estimated to be about 11 million hectares (IRENA, 2017a). Only about $1 \%$ of palm oil produced in Indonesia was used for biodiesel in 2008, but this ratio was increased to 10\% in 2014 (IRENA, 2017a). Although Indonesia only has subsidy policies related to biodiesel, there is Renewable Fuel Standard of E3 for bioethanol (Table 3). Although ethanol subsidy programs are currently

26) Biomass conversion processes, devices, etc. to produce renewable fuel, chemicals, power, etc. 
not implemented due to the lack of incentives for suppliers, it can be inferred that Indonesia is consistently producing bioethanol.

\subsubsection{The Philippines}

The Philippines is a country comprised of three major islands including Luzon, Visayas and Mindanao and 7,107 other islands. In the renewable energy consumption sector, the government of the Philippines set a target to increase the use of renewable energy by at least three times from 2010 to 2030 (IRENA, 2017b). The Biofuel $\mathrm{Act}^{27)}$ was enacted in 2007 to provide a legal quota for biofuel. Renewable Fuel Standard is gradually increasing, and the blend rate was increased from $5 \%$ to $10 \%$ for bioethanol and from $1 \%$ to $2 \%$ for biodiesel (IRENA, 2017b). Further, the country has specific blend rate targets such as E20 by 2020 and B20 by 2025 (Table 3). This indicates expansion of production and supply capacities. The facilitation of biofuel use in the transportation sector leads to growth of the domestic sugarcane industry and cultivation of coconut and other fat-rich plants. However, according to IRENA (2017b), prices of biofuel (biodiesel) produced in the Philippines are gradually increasing despite various benefits including tax exemptions and public subsidies. Since increasing prices make it difficult to satisfy Renewable Fuel Standard of 5\%, the government of the Philippines must present a method of overcoming such problem or lower the target.

\subsubsection{Thailand}

Thailand has been encouraging the use of biofuel for several years, but the targets in the past were not fulfilled. Only about $6 \%$ of fuel demand was fulfilled in 2015 (IRENA, 2017c). The Ministry of Energy is focusing on the development of alternative energy and

27) Biofuels Act, 2006, Republic Act No. 9367. renewable energy sources to secure new energy resources and provide inexpensive energy to citizens of Thailand. The 2012-2021 AEDP ${ }^{28)}$ stipulates that the ratio of renewable energy and alternative energy will be increased to $25 \%$ and the use of biofuels such as bioethanol and biodiesel in transportation will be supported. To accomplish such goals, Thailand established the Fund for Energy Service Companies ${ }^{29)}$ for the renewable energy development project, as well as an incentive program and mechanism to subsidize and facilitate investment in the Energy Conservation Fund $^{30)}$ (APEC, 2015). Despite the fact that Thailand currently has 23 bioethanol refinery plants with average daily capacity of 4.69 million liters and 12 biodiesel refinery plants producing about 6.52 million liters, it seems necessary to significantly increase the refining capacity in order to meet the AEDP target (IRENA, 2017c).

\subsubsection{Others (Vietnam, Myanmar, and Malaysia)}

In 2015, the government of Vietnam established its first renewable energy strategy for 2030, which also includes a vision for 2050 (APEC, 2015). Vietnam aims to increase the rate of biofuel to $5 \%$ of total transportation fuel (about 0.8 Mtoe) by 2020 and 13\% (3.7 $\mathrm{Mtoe}^{31)}$ ) by 2030 (APEC, 2015). In addition, the scope of $R \& D$ activities in Vietnam was expanded to the demonstration of biodiesel production using a non-food crop called Jatropha in the last two years and the study of cellulosic biofuel. Driven by the Biofuel Development Scheme, Vietnam approved a budget of 43,376 million VND ${ }^{32)}$ in 2009. From 2009 to 2011, $22 \mathrm{R} \& \mathrm{D}$ projects and 5 pilot biofuel production projects
28) Alternative Energy Development Plan
29) Fund for Energy Services Companies
30) Energy Conservation Fund
31) Million tons of oil equivalent
32) Vietnamese Dong (national currency of Vietnam) 
were granted to different organizations and individuals (Trinh, 2018).

In Myanmar, five biofuel plants were constructed between 2003 and 2010, annually producing about 19.5 gallons of biofuel (ADB, 2016). In 2009, the government of Myanmar issued a notice permitting production, transport and sales of biofuel to encourage the use of biofuel in place of gasoline (ADB, 2016). As for GHG reduction, the government of Myanmar is placing efforts on GHG reduction by increasing growth of renewable energy to $5 \%$ of $\mathrm{BAU}^{33)}$ by 2020 and $25 \%$ by 2030 (APEC, 2015).

There are sugarcane farms in Malaysia to manufacture raw sugar, but they cannot produce bioethanol due to limited facilities and high cost of ethanol production. Sugarcane produced in Malaysia is mostly sold in Malaysia as syrup. There was an attempt to produce ethanol, but it failed due to the lack of advanced technologies and high capital investment (USDA, 2017).

\subsection{Policy implications}

The U.S. and the EU implemented biofuel policies in response to explosive farm surpluses such as crops and oilseeds that started to occur since 1970s. Ultimately, they gained positive effects such as response to climatic changes and creation of jobs in rural areas. As a representative example, Nebraska in the U.S., which did not have enough competitiveness to export crops because of high logistics cost caused by long distance from the coast, showed increase of farm employment after production of bioethanol (Goto, 2012).

In the case of the ASEAN countries, implications of Renewable Fuel Standard and biofuel policies can be summarized as below. The ASEAN countries have been trying to resolve the future problem of climatic

33) Business as usual, prospective greenhouse gas emission change despite many technical restrictions related to biofuel. The ASEAN countries still do not have an organized system for supporting biofuel policies, and it would be necessary to implement a system reflecting characteristics of each country and region. For example, the Philippines must decide its Renewable Fuel Standard by estimating biofuel production based on raw crops, reflecting characteristics of an island country.

\subsubsection{Environmental issues, R\&D status and limited factors}

According to RFS II of the U.S., specific cellulosic biofuel must be defined to achieve the minimum life cycle emission target in each category. In addition, RED of the EU sets forth specific criteria for conditions that can affect climatic changes, such as $6 \%$ reduction of GHG by 2020 and nitrogen dioxide emission from farming. RED II proposes a series of policies to increase the ratio of renewable energy in energy consumed in the fields of electricity, heating, cooling and transportation to $27 \%$ by 2030 (EU Commission, 2018).

In general, the ASEAN countries play an important role in reducing global GHG emission because the vast coastal area and thousands of islands that are vulnerable to the effects of the rising sea level belong to the ASEAN countries (IEA 2017). Although per capita GDP of Thailand is lower than global average in terms of GHG emission, Thailand places active policy efforts such as a long-term GHG reduction target from 2015 to 2050 to cope with climatic changes (APEC, 2015). At the Lima COP 20 held in Peru, Thailand announced its commitment to reduce GHG emission by $7-20 \%$ by 2020 based on BAU for energy and transportation (APEC, 2015). However, most of the ASEAN countries including Thailand lack of policies and incentives to support renewable energy, and it is urgent to find a means to overcome this issue. Therefore, they are expected to show the rapid development by adopting 


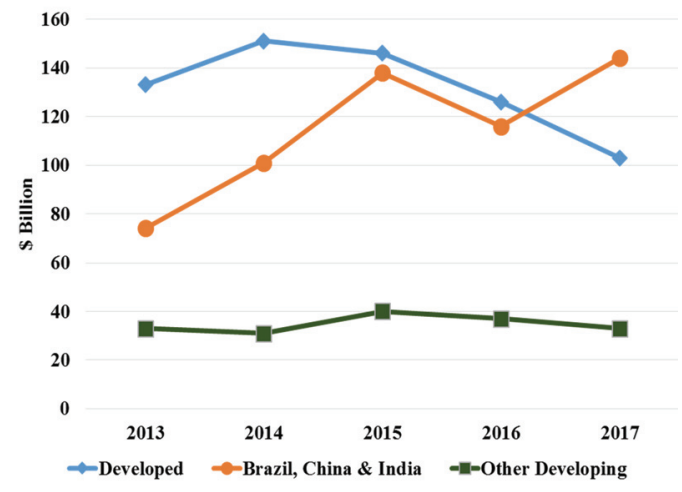

Fig. 4. Global renewable energy investment by type of economy (BNEF, 2018) [Modified, Source: UN Environment].

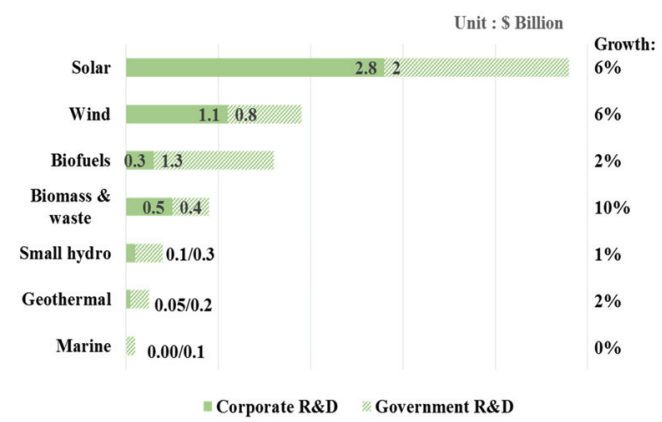

Fig. 5. Distribution of corporate and government R\&D investments in different renewable energy sources (BNEF, 2018)[Modified, Source: IEA, IMF, various government agencies].

excellent economic practices of countries that have already made significant progress in the development and the use of renewable energy, such as the U.S., Brazil and the EU. In addition, increasing introduction of FFV in a market as in Brazil can help increase the use of biofuel in the transportation section. Nonetheless, the production of plants used as raw materials for the first generation (conventional) biofuel is decreasing over time. For example, the production of the first generation biomass for the biofuel pr oduction in Indonesia is predicted to be lowered than
10\% in 2030 (IRENA, 2017a). Countermeasures include the replacement of remaining $90 \%$ with advanced biofuel and the method of expanding farms for the production of first generation biomass. Using advanced ingredients to produce biofuel can help to develop technologies such as hydrolysis and pyrolysis of cellulose. Therefore, problems of policy support, tax benefit and limitations in technology need to be resolved first.

Fig. 4 shows renewable energy investment of developed countries $^{34)}$ and developing countries classified by the OECD. Despite the slight reduction of investment by developed countries until 2016, they generally showed a high ratio of investment. On the contrary, three developing countries including Brazil, India and China took the lead in 2017 with total investment of about 143.6 billion USD. Looking at the ratio of renewable energy investment (Fig. 5), solar energy takes up the largest portion with an overwhelming ratio, followed by wind energy and biofuels.

Solar power generation showed a $6 \%$ growth from 2016 to 2017, recording 4.7 billion USD. Wind power generation recorded investment of 1.9 billion USD. Investment in the biofuels section was increased by about 2\% to 1.7 billion USD ${ }^{35)}$ (BNEF, 2018). According to UNEP, whereas corporate R\&D expenses are responsible for about half of solar and wind power generation, government $\mathrm{R} \& \mathrm{D}$ investment takes up about four-fifths of biofuels. Given such a difficult situation, a $2 \%$ increase can be interpreted as a positive outcome. Research on renewable energy in developing countries is not as active as developed countries, mostly due to the absence of advanced technologies and the lack of research expenses. Accordingly, the scope of biofuel research can be expanded by resolving these problems.

34) Mexico, Chile and Turkey are excluded.

35) Values in Figures 4 and 5 have been rounded off. 


\subsubsection{Enforcement of energy security and sustainable policies}

IRENA $^{36)}$ expects that Indonesia's GDP will increase from $0.3 \%$ to $1.3 \%$ by 2030 but it is only in the energy field (IRENA, 2017a). Jobs related to renewable energy will research over 1.3 million in 2030 which is considerably higher compared to 101,800 jobs in 2015 (IRENA, 2017a). In addition, it is possible to solve insufficient training on renewable energy by establishing a technical education curriculum through expansion of training in rural areas to create jobs. REmap $^{37)}$ anticipates that energy intensity in ASEAN economy will decrease up by approximately 30\% from 2005 to 2025 and this mostly meets the ASEAN's goal to improve energy intensity (IRENA, 2016). Discussions on sustainability of biofuel focus on changes in direct and indirect use of land as well as GHG emission (Frank et al., 2013). Recently, concerns over negative effects of biofuel on biodiversity and loss of habitats were suggested. In conclusion, however, a combination of $\mathrm{REDD}^{38}$ ) and comprehensive policies such as land use transition are considered to be improving overall effects of policies in terms of preservation of biodiversity (Frank et al., 2013). Each government must strive to improve energy security by reinforcing regional and international energy cooperation, diversifying energy income sources and developing renewable energy. As mentioned in chapter 2 and 3, what needs to be noticed when conducting RFS and REDs is that the Renewable Fuel Standard plans have been adjusted down in some cases. In Fig. 5 , there is a difference in the RFS target and the actual consumption of biofuel in Indonesia. It is important to learn that more practical and feasible plan must be set rather than making an impractical plan.

36) International Renewable Energy Agency

37) Renewable Energy Roadmap from IRENA

38) Reducing Emissions from Deforestation and forest Degradation

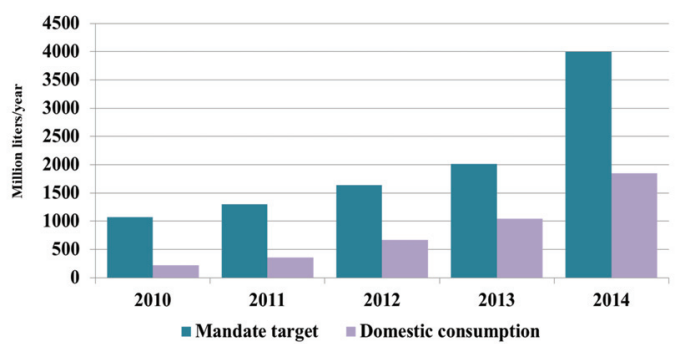

Fig. 6. Indonesian mandatory biodiesel blending targets and actual domestic consumption, 2010-2014 (IRENA, 2017a).

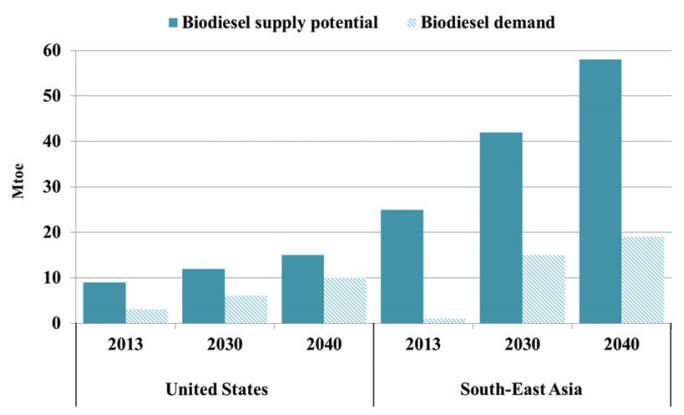

Fig. 7. 2013-2040 Biodiesel supply potential and demand by region (APEC, 2016).

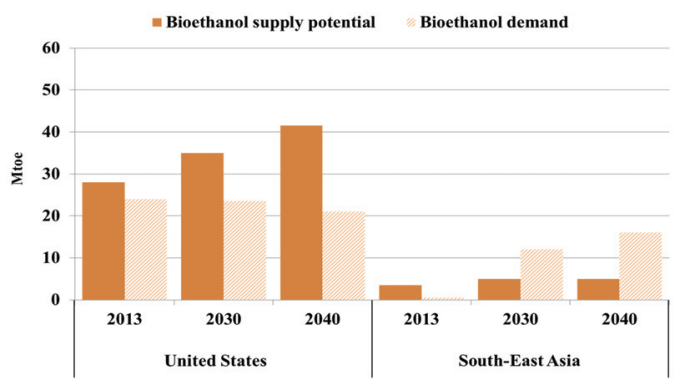

Fig. 8. 2013-2040 Bioethanol supply potential and demand by region (APEC, 2016).

Fig. 7 and 8 show supply potential of biodiesel and bioethanol in the U.S. and South East Asian countries by year and country from 2013 to 2040. Bioethanol demands in South East Asia are steadily increasing in the prospect years because the transportation energy demand is rapidly increasing whilst the potential supply 
is still low (APEC, 2016). Bioethanol production in South East Asia cannot meet the increasing demand from 2030 to 2040, and consequently, some countries must develop and allocate the sources of advanced bioethanol materials or secure additional supplies from overseas producers (APEC, 2016). It is judged that governmental supports are needed for some countries to strengthen existing measures and set the higher blending target to increase the biofuel demands and use available potential.

\section{CONCLUSION}

Biofuels are not something that only exists in laboratories, but they are currently being used as an alternative fuels. Considering that the U.S. and the EU are implementing policies of bioenergy and biofuel at a national level through RFS and RED, it is necessary for ASEAN countries to actively establish policies in this field. Furthermore, in an effort to diversify fuels and cope with climate change, each government can realize sustainable policies by setting a goal to gradually increase Renewable Fuel Standard for biofuels. It is necessary to continue with research on technologies that use cellulosic biomass and microalgae, which can replace the first generation (conventional) biomass considered as a food resource, in future. Subsidy policies, tax benefits and smooth supply of fuels will have a significant effect in the development of biofuel technologies of each country.

As a result of examining the situations of the U.S., Brazil and Europe with high availability of biofuels, it is important to understand the current status of biomass resources in each county for active utilization of biofuels in ASEAN countries. In addition, efficient economic policies of the developed countries such as supply and demand of renewable energy must be reflected to establish necessary laws.

\section{REFERENCES}

ADB. 2016. Myanmar: Energy sector assessment, strategy, and road map. Mandaluyong City, Philippines: Asian Development Bank. ISBN 978-92-9257-685-1.

APEC, 2015. APEC Energy Overview 2015. Asia Pacific Energy Research Centre (APERC). APEC\#215-RE-01.15.

APEC, 2016. Energy Demand and Supply Outlook $6^{\text {th }}$ Edition. Asia Pacific Energy Research Centre (APERC). APEC\#216-RE-01.8. ISBN 978-981-098921-7.

Bloomberg New Energy Finance (BNEF), Global Trends In Renewable Energy Investment. 2018. Frankfurt School-UNEP Center, https://fs-unepcentre.org/

Boutesteijn, C., Drabik, D., Venus, T. J. 2017. The interaction between EU biofuel policy and first-and second-generation biodiesel production. Industrial Crops and Products 106: 124-129.

Bracmort, K. 2015. The renewable fuel standard (RFS): cellulosic biofuels. Congressional Research Service 7-5700.

Brazil biofuels. 2016. https://www.transportpolicy.net/ standard/brazil-fuels-biofuels/.

Cho, J.H., Lee, H.S., Yang, E.M. 2013. A foreign case study of renewable fuel standard with respect to biogas. Korea Environment Institute 17-254.

Council of the EU. 2017. http://www.consilium.europa. eu/en/press/press-releases/2017/12/18/promoting-r enewable-energy-use-council-adopts-its-position/.

Directives. 2009. Directive 2009/28/EC of the European parliament and of the council of 23 Apr. 2009 on the promotion of the use of energy from renewable sources and amending and subsequently repealing Driectives 2001/77/EC and 2003/30/EC. Official Journal of the European Union, L 140/16.

Dixon, P., van Meijl, H., Rimmer, M., Shutes, L., 
Tabeau, A. 2016. RED versus REDD: Biofuel policy versus forest conservation. Economic Modelling 52: 366-374.

DOE (Department of Energy). 2017. https://www.afdc. energy.gov/laws/RFS.html.

EU Commission, 2018. https://ec.europa.eu/energy/en/ topics/renewable-energy/renewable-energy-directive.

Frank, S., Böttcher, H., Havlík, P., Valin, H., Mosnier, A., Obersteiner, M., Schmid, E., Elbersen, B., 2013. How effective are the sustainability criteria accompanying the European Union 2020 biofuel targets?. Gcb Bioenergy 5(3): 306-314.

Goto, Y. 2012. The world is changed by resources, food and energy. Chapter 1. Fantastic resources, food crisis. Japanese Economic Newspaper Publisher, Chiyoda-ku, Tokyo, Japan.

Goto, Y. 2012. The world is changed by resources, food and energy. Chapter 2. Strength of energy diversity. Japanese Economic Newspaper Publisher, Chiyodaku, Tokyo, Japan.

Heo, S.J., Choi, J.W. 2017. Study on utilization and prospect of Lignocellulosic Bioethanol in ASEAN countries. Journal of the Korean Wood Science and Technology 45(5): 588-598.

IRENA. 2016. Renewable Energy Outlook for ASEAN: a REmap Analysis. Abu Dhabi and ASEAN Centre for Energy (ACE), Jakarta. ISBN 978-92-9511127-1.

IRENA. 2017a. Renewable Energy Prospects: Indonesia, a REmap analysis, International Renewable Energy Agency (IRENA), Abu Dhabi, www.irena.org/ remap. ISBN 978-92-95111-18-9.

IRENA. 2017b. Renewables Readiness Assessment: The Philippines, International Renewable Energy Agency, Abu Dhabi. ISBN 978-92-9260-003-7.

IRENA. 2017c. Renewable energy outlook: Thailand. International Renewable Energy Agency, Abu Dhabi. ISBN 978-92-9260-035-8.

Kim, Y.S. 2016. Current status and prospects on Biofule Conversion Technologies and Facilities, using Lignocellulosic Biomass. Journal of the Korean Wood Science and Technology 44(5): 622-628.

Trinh, T. A., Le, T.P.L. 2018. Biofuels potential for transportation fuels in Vietnam: A status Quo and SWOT analysis. IOP Science, 143, 012065.

USDA. 2015. Global Agricultural Information Network (GAIN), Jakarta, Indonesia. ID1525.

USDA. 2017. Global Agricultural Information Network (GAIN), Malaysia, MY7007.

USDA. 2017. Global Agricultural Information Network (GAIN), Brazil, BR17006.

Park, T.J. 2011. Biorefinery overseas status and policy implications. Korea Environment Institute, 15-06.

Stock, J. 2017. Proposed Denial of Petitions for Rulemaking to Change the RFS Point of Obligation: Docket ID No. EPA-OAR-2016-0544. Cambridge, MA, USA. 


\title{
APPENDIX
}

\author{
(Korean Version)
}

\section{선진국 사례분석을 통한 ASEAN 국가의 바이오연료 활용 방안 및 시사점}

요약 : ASEAN 국가는 광대한 연안과 수 천 개의 섬들로 이루어져 있어 기후변화로 인한 해수면 상승은 국가의 존립에 큰 위기요인이다. 이로 인해 ASEAN 각 국가가 입게 되는 피해를 최소한으로 줄이기 위해서는 범국가적인 온실가스 배출량을 감축하기 위한 노력이 중요하다. 기후변화에 대비하기 위한 다양한 방안 중 하나인 바이오연료는 이를 화석연료를 대체함으로써 환경에 미치는 영향을 최소화하고 온실가스 감축 효과를 불러올 수 있다. 바이오연료 선진국인 유럽과 미국, 브라질은 이 분야에 대한 연구와 개발 및 투자가 이전부터 활발하게 진행되고 있었던 반면 ASEAN 국가에서 관련 정책이 제정 된 것은 긴 시간이 지나지 않았다. 따라서, 본 연구에서는 바이오연료 선진국 중, 바이오에탄올 중심의 미국과 브라질, 바이오디젤 중심의 유럽 연합(EU)의 의무혼합제도와 바이오연료 보급 정책을 각각 살펴보았다. 또한 이를 바탕으로 현재 시행되고 있는 ASEAN 국가의 바이오연료 활용방안과 전망을 모색하였다.

\section{1. 서 론}

지구온난화로 인한 해수면 상승과 각종 유해물질의 증가 등의 환경문제는 국제적인 문제가 되었으며 재생에너지 개발과 활용은 모든 국가가 해결해야 할 과제라고 할 수 있다. 이에 따라 세계적으로 화석연료를 대체할 수 있는 재생에너지 연구가 각광을 받게 되었다. 바이오연료를 활용하여 얻게 되는 대표적 기대효과로는 기후변화 완화와 에너지 안보 향상, 그리고 농촌지 역의 고용창출 등이 있다.

대표적인 바이오연료는 발효 공정을 통해 생산되는 미국의 옥수수, 브라질의 사탕수수 기반 바이오에탄올과 유럽연합(EU)에 서 지방종자 등으로부터 알킬 에스테르화 공정을 거쳐 만들어지는 바이오디젤이 있다. 바이오연료는 이와 같이 현실적 대체연료 로서 이용되고 있으나 ASEAN은 미국과 유럽연합 등이 바이오매스 활용을 위해 활발한 정책을 펼치고 있는 것과는 거리가 있다. 현재 선진국과 같은 수준의 정책을 시행하기에는 무리가 있으나 그 사례를 통하여 향후 효과적인 바이오연료 정책을 시행할 것으로 기대된다. 저자는 이전 논문으로 ASEAN 국가에서의 목질계 바이오에탄올의 활용 및 전망에 관한 연구를 하였다 (Heo and Choi, 2017). 그러나 기술적 한계성으로 인하여 바이오연료 정책을 시행함에 있어 제한 사항이 다수 있음을 확인하였 다. 따라서 이를 보완할 수 있는 방안을 찾고자 이 연구를 진행하게 되었다. 현재 목질계 바이오에탄올 시장의 규모와 기술의 현황으로서는 각국의 목표량에 대체하기에 매우 부족한 상황이다(Kim, 2016). 선진국 사례를 분석하여 국내 상황에 적용한 연구 사례(Cho and Lee, 2013; Park, 2011)는 있으나 본 연구는 ASEAN의 상황을 기반으로 연구되었으므로 그 의의가 다르다고 할 수 있다. 본 연구에서는 바이오에탄올 중심의 미국과 브라질, 그리고 바이오디젤 중심의 유럽연합(EU)의 의무혼합제도와 바이오연료 보급 정책을 각각 살펴보았다. 이와 함께 Renewable Fuel Standard(RFS)와 Renewable Energy Directives(RED)의 정책 배경과 계획 등을 정리하였고 해외사례로서 미국과 브라질, 유럽의 바이오연료 활용방안을 분석하였다. 또한 ASEAN에서 현재 시행되고 있는 바이오연료 정책 사례를 조사하였고, 이를 바탕으로 선진국에서의 관련 정책 사례를 통해 ASEAN의 현 시점에서 개선될 필요가 있는 부분에 대한 정책 시사점을 모색하였고 결론을 도출하였다.

\section{2. 재료 및 방법}

\subsection{RFS}

RFS는 2005년 미국에서 에너지 정책 에 의해 제정되었으며 2007년, EISA 에 의해 그 범위가 확대되었다. 이는 미국 내 운송분야 에서 바이오연료 의무혼합률을 부과하기 위해 처음 시행되었으며, 여기서 사용되는 바이오연료의 개념은 1 세대를 비롯한 2 세대 바이오에탄올과 바이오디젤 모두를 포함한다(Bracmort, 2015). RFS I의 주요 내용은 바이오연료의 의무혼합률 제시와 RIN 을 기반으로 한 추적시스템과 사업자 관리를 위한 일반 면제 조항을 담고 있다(Cho and Lee, 2013). DOE 에 따르면, 의무 당사자는 요구되는 바이오 연료 양을 판매하거나 요구 사항을 초과하는 당사자로부터 RIN을 구입함으로써 재생 가능한 양적 책임 을 충족시킬 수 있다. 따라서, 해당 기업은 이에 계산된 바이오연료의 양 만큼의 RIN을 보유하고 있어야 하는 데 만약 그렇지 않다면 
하루 최대 32,500 USD가 벌금으로 부과된다(Cho and Lee, 2013).

그러나 RFS I의 목표에 충족하지 못하는 경우가 생겨 하향 조정하는 사례가 생겼고, 2010년, RFS I(2007)을 보완하기 위해 RFS II가 등장하게 되었다. 이는 RFS I과 달리 구체적으로 바이오연료의 종류에 대하여 정의하였고, 이에 따른 현실적 인 의무혼합률 목표를 제시하였다(Bracmort, 2015). DOE에서 정의한 바이오연료는 석유와 비교하여 전주기 온실가스 (GHG) 배출 감축의 특정 최소 목표값을 달성해야 하며 그 기준은 다음과 같다; 1 )기존 1 세대 바이오연료 - 전주기 GHG의 $20 \%$ 이상 감축, 2)첨단 바이오연료 - i. 바이오디젤 - $50 \%$ 이상 감축, ii. 목질계 바이오연료 - $60 \%$ 이상 감축을 요구한다. 미국 환경보호국 (EPA)은 RFS 프로그램을 관리하고 EISA 법령에 의거 한 양과 연료 가용성에 따라 각 카테고리의 양의 요구사항을 설정한다(DOE, 2017). 일반적으로 미국 환경 보호국 은 목질계 바이오연료의 의무혼합률에 부과할 양을 정하기 위해 각각의 생산자와 EIA, USDA, DOE와의 토론을 통해 얻어진 개별적인 생산계획과 진행 속도 등의 정보를 바탕으로 평가한다(Bracmort, 2015). 그림 1에서는 해마다 대체적으로 증가하는 바이오연료 의무혼합률을 예측하고 있다. 일정한 비율 을 보이는 1 세대 바이오연료(Conventional)와 바이오디젤과 비교하여 목질계 바이오연료와 첨단 바이오연료는 증가 양상을 보이는 것을 알 수 있다.

\subsection{RED}

$\mathrm{EU}$ 는 2009년, 재생가능에너지 지침(RED)을 제정하였는데, 그 목표는 각 국가 또는 지역마다 다르게 책정되고 있다. $\mathrm{RED}$ 는 바이오에탄올과 바이오디젤과 같은 바이오연료의 사용을 위한 최소 수준을 부과함으로써 GHG 배출 및 화석연료 의존도를 줄이기 위한 지침이다(Dixon et al., 2016). 유럽집행위원회 에서는 2020년까지 수송 분야에서 바이오연료를 $10 \%$ 까지 증가시키며 6\%의 GHG 감축을 목표로 설정하였다(Dixon et al., 2016; EU Commission, 2018). 또한 재생에너지 분야에서는 2016년에 2030 년까지 전체 에너지 필요량의 최소 $30 \%$ 충족을 목표로 설정하였으나 몰타의 경우 $10 \%$ 에서 스웨덴의 경우 $49 \%$ 까지 국가마다 다른 목표를 가지고 있다. 그리고 1년 후인 2017년 12월에 재생에너지 분야를 $27 \%$ 로 목표를 하향 조정하였는데 보통 $\mathrm{EU}$ 국가들은 이러한 목표를 통해 2년 성과를 기반으로 국가 목표를 재설정 할 수 있다 (Council of the EU, 2017). RED는 $\mathrm{EU}$ 국가들과 그 외의 국가들 간의 협력을 통해 재생에너지 목표를 달성하도록 도울 뿐만 아니라 EU에서 생산되거나 소비되는 모든 바이오연료에 대해 지속가능하고 친환경적인 방식으로 생산하기 위한 지속 가능성 기준을 제시한다. 그 예시로 첨단 바이오연료의 최소 점유율은 2021 년에 최소 $0.5 \%$ 에서 2030 년에 3.6\% 이상으로 점진적으로 증가할 것으로 예측되며 이곳에 사용되는 농업 바이오매스는 다음과 같은 기준을 충족해야한다; (1) 높은 생물 다양성 가치를 가지며, (2) 탄소 축적량이 낮은 토지에서 자란 원료를 기반으로 생산되는 것이어야 한다(Council of the EU, 2017). 바이오연료 생산 기업은 이러한 지속 가능성 기준 또는 유럽 진행위원회에서 인정하는 자발적 계획을 통해 준수 여 부를 입증 할 수 있다. 그러나 여기서 말하는 바이오연료는 주로 1세대 기반이며 이를 보완하기 위해 2016년에 RED II를 제정하였다. 이는 2030년을 기준으로 $6.8 \%$ 연료 혼합을 목표로 하며 기존 RED와 달리 1 세대 연료를 배제한 첨단 바이오 연료를 기준으로 한다(EU Commission, 2018). 또한, 기존 RED가 연료공급자의 전주기 GHG 배출량 감축의 의무를 부과 하며 구체적으로 어떠한 경우가 GHG 배출에 포함되는지에 관한 기준을 세웠다; 1) 경작 시 토양 이산화질소 배출량, 2) 식물성 기름 추출 시 배출량, 3) 최종 연료 수송 및 분배 시의 배출량 등이 포함된다.

\section{3. 결과 및 고찰}

3.1 바이오연료 선진국 사례

3.1.1. 미국

미국은 세계 에탄올의 절반 가까운 양을 생산하며 그 원료는 대부분 옥수수를 기반으로 생산된다. 2009년에는 1 억 700만t, 2010 년에는 1 억 1,200 만의 옥수수를 에탄올 생산에 이용하였는데, 이는 미국 옥수수 생산량 전체의 대략 3 분의 1 , 세계 생산량 의 $13 \%$ 나 되는 양이다(Goto, 2012).

$\mathrm{EPA}$ 는 현재 $\mathrm{E} 10$ 에서 $\mathrm{E} 15$ 에 대해 검토하고 있으며 에너지 안보 개선을 위해 바이오연료 분야에 강력한 정책을 시행하고 있다(Park, 2011). 최근에는 첨단 바이오연료에 주목하고 있는데 이를 위해 오클라호마 주에서는 가솔린에 함유된 옥수수 유래 바이오에탄올 1갤런당 45센트의 세액공제 제도 폐지를 장려하고 있다(Park, 2011). Goto(2012)에 의하면, 미국은 1978년부 터 바이오에탄올을 $10 \%$ 이상 포함한 휘발유에 대한 연방세를 감면해 왔으며 2004년에 주유소 에탄올 급유설비 비용에 대한 세액공제 등 다양한 바이오연료 우대정책을 도입해 왔다. 주 단위로 보면, 일리노이 외 10 개 주가 휘발유 판매세 감면, 미네소타 
외 17개 주가 바이오에탄올 공급업자에 대한 보조를 시행하고 있다(Goto, 2012). 그림 2에서는 미국 내 주요 도시에서 의무혼합 률에 해당하는 바이오에탄올 생산하는 공급업체의 위치를 나타낸 것으로 고 혼합연료를 생산하는 곳은 걸프만과 중서부에 있다는 것을 볼 수 있다. EISA는 2022년까지 2009년에 420억 리터 (11억 갤런)에서 최대 1360억 리터 (360억 갤런)로 증가 시킬 것을 목표로 설정하였다(APEC, 2015). 그러나 이러한 목표는 비용이 너무 높다고 판단되거나 바이오연료의 공급이 불충분 할 경우 하향조정이 가능하다는 조항을 포함하고 있다. 예시로, EPA는 2007 년에 의회가 구상 한 222.5 억 갤런/연 에 미치지 못하였으나, 2016 년까지 총 180억 갤런/연 이상으로, 이후 2022년까지 150 억 갤런/연 의 바이오에탄올을 생산하는 것으로 목표를 하향 조정하였다(APEC, 2015; APEC, 2016).

\subsection{2. 브라질}

브라질은 1973년 일어난 제 1차 석유파동으로 높아진 화석연료 수입의 의존성을 줄이기 위해 1975년 국가 알코올 프로그 램(National Alcohol Program)이 제정되었다. 2011년에는 바이오에탄올의 가용성이 낮아 원래 목표였던 E25를 충족하지 못 하고 E20까지 떨어졌으나 2012년 6월에 회복하였으며, 2015년 의무혼합률은 E27로 증가하였다(USDA, 2017). 바이오에탄올 의 실제 소비량은 표준보다 높다고 할 수 있는데 이는 가솔린 혼합 외에도 FFV 와 같은 차량에서 순수 에탄올을 소비하기 때문이다 (Brazil biofuels, 2016). 브라질에서 생산되는 대부분의 바이오에탄올은 국내에서 재배된 사탕수수 기반이며 이의 생산량은 2003년에 약 3억 9,600만 톤에서 2009년에 약 6억 7,139만 톤으로 늘어났는데 이는 6년만에 약 1.7 배가 늘어났다고 볼 수 있다(Goto, 2012). 2004년 12월부터 브라질은 전국적으로 바이오디젤 생산 증가를 위한 국가 바이오디젤 생산 및 사용 프로그램 을 실시하였다(Brazil biofuels, 2016). 이 프로그램의 목표는 법률, 행정 및 규범적 조치를 요구하며, 바이오디젤에 대한 연방세 모델을 정의하고, 생산자와 수입자 등록 조건을 수립하는 것이다. USDA(2017)에 의하면, 국가 에너지 정책위원 회 는 의무혼합률 목표로 2017년 B 8, 2018년 B9, 2019년에 B10-B15까지 점차 증가 시킬 것을 요구하였다. 실제로, USDA(2017)에 따르면, 2017년 미국 내 바이오에탄올 의무량은 E27 로 일정한 반면, 바이오디젤의 경우 B8로 증가하였다. 브라질 바이오디젤 원료의 가장 일반적인 유형의 콩 바이오디젤은 GHG 배출량을 RFS II와 RED 기준에서 각각 $57 \%$ 와 $31 \%$ 감소시키는 것으로 평가되었다(Directives, 2009). 그러나 브라질 바이오연료 정책에서는 환경 지속 가능성 기준이 별도로 없으며 예시로, GHG배출 감축 수준과 간접 토지 이용 또한 고려되지 않는다(Brazil biofuels, 2016). 브라질에서 생산되는 사탕수수 기반 에탄올은 EPA의 RFS II에 따르면 $61 \%$ 의 GHG 배출량 감축에 기여한다고 평가되었으며, EU의 RED 기준에 의하면 약 $71 \%$ 의 감축효과를 가진다고 평가되었다 (Directives, 2009). 그림 2에서는 브라질의 지역 및 주 별로 구별하여 나타낸 것이며 표 1에서 기획부(Ministry of Planning)에서 설정한 2017년 7월 현재 브라질의 각 주에 따른 ICMS 를 보여준 다. 바이오에탄올에 부과되는 ICMS는 $12 \sim 30 \%$ 로 다양하며 휘발유의 경우 $17 \sim 34 \%$ 이다. 보통의 경우, 바이오에탄올과 가솔린의 ICMS가 같거나 가솔린이 더 높은 경우가 대부분이며 이것으로 인해 바이오연료 생산에 대한 세제 혜택이 존재한다 는 것을 알 수 있다.

\subsection{3. 유럽 연합(EU)}

$\mathrm{EU}$ 는 2010년에 바이오디젤유를 생산하기 위해 약 1,680 만의 채종과 해바라기 등의 지방종자를 소비하였는데, 이는 지방종 자 전체의 70\%에 가까운 양이다(Goto, 2012). EU의 수송 부문에서 바이오연료는 2009-2013 년에 걸쳐 총 연료 사용량의 약 $4 \%$ 를 차지하였으며, 이 중, 바이오디젤이 $75 \%$ 의 점유율을 차지한다(Boutesteijn et al., 2017).

최근 $\mathrm{EU}$ 는 RED를 통해 2020 년까지 현재 에너지 소비의 $20 \%$ 와 총 운송 연료 수요의 $10 \%$ 가 재생에너지원을 기반을 목표로 설정하였는데, 바이오에너지 부문 (바이오연료 및 바이오매스)이 실질적으로 기여할 것으로 예상된다 (Frank et al., 2013). 각 EU국가는 서로 다른 가용 자원과 고유한 에너지 시장을 가지고 있는데 이는 각 국가마다 RED를 준수하기 위해 다른 목표를 가지고 있다는 것을 의미한다. 2020년을 기준으로 2007년 유럽 정상들 간에 합의한 '에너지 행동계획 '에서는 유럽의 수송용 연료 중 바이오연료의 사용을 2010년 5.75\%에서 2020년 10\%까지 증가 시킬 것을 요구하였다(Cho and Lee, 2013). EU Commission은 2030년까지 EU 최종 에너지 소비에서 최소 $27 \%$ 의 재생에너지 목표에 대한 제안서를 발표했다. 현재 시행되고 있는 $\mathrm{RED}$ 는 몰타의 $10 \%$ 이하에서 스웨덴의 $49 \%$ 까지 다양하다. 이러한 목표를 향한 진전 상황은 각 국가가 2 년 주기로 보고서를 작성한다.

표 2에서와 같이 일부 $\mathrm{EU}$ 국가에서는 각 바이오연료에 관한 의무혼합제도를 시행하고 있는데 루마니아의 에탄올 혼합 비율이 가장 높았으며 그 뒤는 오스트리아와 스페인이 뒤를 이었고, 디젤 분야에서는 루마니아와 스페인이 공동 1 위, 다음으로 
그리스와 오스트리아 순으로 높았다.

독일에서는 바이오연료 할당법 을 시행하여 2014년까지 6.25\%까지 사용을 의무화하였다(Park, 2011). 예산 지원 방법으로서 는 크게 두 가지로 나눌 수 있는데 첫째로, 세금 공제나 보조금 지원 혜택을 제공하는 것과 둘째, 의무혼합제도와 같은 규제를 제공함으로써 바이오연료의 일정 시장 점유율을 보장하여 세금 공제와 보조금 지원보다 정부의 재정 부담을 최소화하는 것이 있다(Cho and Lee, 2013). 또한, 영국에서의 2008년 4월부터 추진된 재생교통연료 의무조항 은 유럽연합의 바이오에너지 정책성명을 이행하기 위한 조치로서 영국 내에서 판매되는 가솔린과 디젤에 바이오연료를 최소 $2.5 \%$ 이상 혼합하도록 하고 있으며 2013년까지 수송연료의 5.26\%를 바이오연료로 대체할 것을 목표로 제시하였다(Park, 2011).

\subsection{ASEAN 바이오연료 정책 현황}

재생에너지 자원은 동남아시아에서 풍부하다고 볼 수 있으며, 대표적으로 인도네시아는 세계 팜유산업에서 가장 큰 부분을 차지한다. 의무혼합률 부문에서 인도네시아는 2025년까지 B30을 계획하였고, 팜 유 산업에서 두 번째로 큰 부분을 차지하는 말레이시아는 최근 B7에서 B10으로 높일 것을 발표하였다(APEC, 2016; IEA 2017). 표 3에서는 일부 ASEAN 국가에서 시행하고 있는 의무혼합률과 목표 타겟을 정리해 놓은 것으로 인도네시아와 필리핀은 바이오에탄올 혼합을 $\mathrm{E} 20$ 까지 증가시킬 것으로 목표를 설정하였다. 바이오디젤의 경우 인도네시아는 B30, 필리핀은 B20의 목표를 세웠으며 태국은 각각 E30과 B20의 목표를 설정하였다. 또한 최근, 바이오연료의 경쟁력을 향상시키기 위해 대부분의 ASEAN 국가들은 R\&D 자금 조달, 보조금 및 세금 인센티브를 통해 바이오연료 정책 메커니즘을 제공하고 있다.

\subsection{1. 인도네시아}

지속가능한 생산을 위해 세계 팜유산업의 $40 \%$ 정도를 차지하는 인도네시아는 2015년에 소작농들을 위한 국제인증 제도 를 소개하였다(IEA 2017). 이는 생산량을 증가시키면서도 이전보다 훨씬 환경 친화적인 방법이라고 할 수 있다. 2008년에 인도네시아는 바이오연료의 공급 및 상업적 판매에 관한 장관급 규정 No. 32/2008을 다른 연료처럼 이용 가능하도록 법으 로 통과시켰다(APEC, 2015). 이는 2009년부터 바이오연료 소비 의무를 가능케 했으며 다음과 같은 사항을 규제하고 있다; 1) 바이오연료 분류; 2) 품질 표준 및 규격; 3) 가격 설정; 4) 지시 및 감독; 5) 제재 등의 항목이 있다(APEC, 2015). 인도네 시아에서의 바이오디젤 생산은 2009년에 약 19,000 만 리터(약 5,000 갤런) 생산에 그쳤으나 2014년에 296100 만 리터(약 7.8억 갤런)로 급증 하였으며, 바이오리파이너리 공장도 7개에서 26개로 늘어났다(USDA, 2015). IRENA(2017a)에 따르면 2015년에 인도네시아의 국내 의무혼합률이 B10에서 B15로 증가하였고 그 원료 작물인 팜유의 생산성을 충당하기 위해 새로운 팜 유 부동산 기금 청(Estate Fund Agency)이 신설되었다고 한다. 인도네시아 대부분의 바이오디젤은 팜 유 기반이 며 오늘 날 팜 유의 경작지는 약 1,100 만 헥타르(Mha) 정도 인 것으로 추정된다(IRENA, 2017a). 팜 유는 2008년 인도네시 아의 총 생산에서 오직 $1 \%$ 정도가 바이오디젤로 이용되었지만 2014년에는 10\%까지 증가하였다(IRENA, 2017a). 인도네시 아에서는 주로 바이오디젤에 관련된 보조금 정책만 있지만 바이오에탄올 또한 E3의 의무혼합률 목표가 있다(표 3). 비록 에탄올 보조금 프로그램은 공급업체에 불충분한 인센티브 등으로 인해 현재는 시행되지 않고 있으나 바이오에탄올은 꾸준 히 생산되고 있다는 것을 유추할 수 있다.

\subsection{2. 필리핀}

필리핀은 3개의 주요 섬인 Luzon, Visayas, Mindanao와 그 안의 7,107개의 섬들로 이루어진 국가이다. 필리핀 정부는 재생에 너지 사용 부문에서 2010년 대비 2030년까지 3배 이상 증가 목표를 설정하였다(IRENA, 2017b). 2007년에 바이오연료법 이 2007년에 도입되었는데, 이는 바이오연료의 법적 의무할당량을 제공한다. 이러한 의무혼합률은 점차적으로 증가하고 있으며 과거에 비해 바이오에탄올은 $5 \%$ 에서 $10 \%$ 로, 바이오디젤은 $1 \%$ 에서 $2 \%$ 로 각각 올랐다(IRENA, 2017b). 또한, 2020년까지 E20, 2025년까지 B20 혼합의 구체적인 목표를 갖추고 있다(표 3). 이것은 생산 및 공급 능력의 확대를 의미하며, 운송 부문에서 의 바이오연료 사용 촉진은 국내 사탕수수 산업의 성장과 코코넛 및 기타 지방이 풍부한 식물의 재배를 유도하게 된다. 그러나 IRENA(2017b)에 따르면, 세금 면제와 공공 기관을 통한 보조금 등 다양한 혜택에도 불구하고 필리핀 내에서 생산된 바이오연료 (바이오디젤)의 가격이 점점 상승하는 추세이다. 이는 결론적으로 현재 의무혼합률인 $5 \%$ 를 충족시키기 어렵게 만들며 필리핀 정부는 이와 같은 문제를 극복하기 위한 방안을 제시하거나 목표를 하향 조정하는 등 재설정이 필요하다고 보여진다.

3.2.3. 태국 
태국의 경우, 수년 동안 바이오연료의 사용을 장려해 왔지만 과거 목표 수치는 충족되지 못하였으며 2015년에는 연료 수요의 약 6\%만이 충족되었다(IRENA, 2017c). 에너지 부(Ministry of Energy)에서는 새로운 에너지 자원을 확보하고 태국 시민에게 저렴한 에너지를 제공하기 위해 대체 에너지와 재생에너지를 개발하는 데 힘을 기울이고 있다. 2012-2021 AEDP 에는 재생에너 지 및 대체에너지의 비율을 $25 \%$ 까지 증가시킨다는 내용을 담고 있으며 바이오에탄올과 바이오디젤과 같은 운송 바이오연료의 사용을 지원할 것이라고 명시하고 있다. 이러한 목표를 달성하기 위해 태국은 재생에너지 개발 프로젝트를 위한 에너지 서비스 기금 및 에너지 절약 기금 의 보조금과 투자 촉진을 위한 인센티브 프로그램 및 메커니즘을 수립하였다(APEC, 2015). 태국은 현재 하루 평균 총 수용 용량이 4.69 million L인 23개의 바이오에탄올 리파이너리 공장과 약 652 만 리터를 생산하는 12 개의 바이오디젤 리파이너리 공장을 보유하고 있음에도 불구하고 $\mathrm{AEDP}$ 의 목표를 유지하기 위해서는 리파이닝 용량의 상당한 증가가 필요할 것으로 판단된다(IRENA, 2017c).

3.2.4. 기타 (베트남, 미얀마, 말레이시아)

2015년, 베트남 정부는 국내 최초로 재생에너지에 관한 2030년 목표 전략을 세웠는데 이는 2050년까지의 비전 또한 포함하고 있다(APEC, 2015). 바이오연료 분야에서는 2020년까지 총 운송 연료 부문의 $5 \%$ (약 0.8 Mtoe )와 2030년까지 $13 \%$ (3.7 Mtoe ) 차지하는 것을 목표로 설정하고 있다(APEC, 2015). 또한, R\&D 활동으로는 최근 2년 동안 비 식량 작물 인 자트로파(Jatropha)를 이용해 바이오디젤을 생산하는 시범 사업과 목질계 바이오연료 연구까지 그 분야가 확대되었다. 2009년에는 바이오연료 개발 계획(Biofuel Development Schme)의 주도 하에 총 VND 43,376백만의 예산이 승인되었으 며 2009-2011년의 기간 동안 22개의 R\&D 프로젝트 및 5개의 파일럿 바이오연료 생산 프로젝트가 각 조직과 개인에게 부여되었다(Trinh, 2018).

미얀마에서는 2003년과 2010년 사이에 5 개의 바이오연료 공장이 건설되었으며 연간 약 1,950 만 갤런을 생산하고 있다(ADB, 2016). 2009년에 미얀마정부는 일반 가솔린 대신 바이오연료의 사용을 권장하기 위해 이에 관한 생산 및 운송, 판매를 허용하는 통지서를 발급하였다(ADB, 2016). GHG 감축 부문에서 미얀마 정부는 재생에너지의 성장이 2020년까지 BAU 대비 약 $5 \%$, 2030 년까지 약 $25 \%$ 이상 완화시키기 위해 노력하고 있다(APEC, 2015).

말레이시아에는 원당 제조를 위한 사탕수수 재배지가 있으나 한정된 규모와 에탄올 생산의 높은 비용으로 인해 바이오에탄올 생산이 불가능한 실정이다. 생산되는 사탕수수는 주로 말레이시아 내에서 주로 시럽으로 판매되고 있으며 에탄올 생산 시도가 있었으나 선진기술의 부재와 높은 자본 투자 문제로 인하여 시행되지 못하였다(USDA, 2017).

\section{3. 정책 시사점}

미국과 EU는 1970년대부터 대폭적으로 발생한 곡물과 지방종자의 잉여농산물에 대응하기 위해 바이오연료 정책을 펼쳤으나 궁극적으로 이를 통해 기후변화에 대한 대응과 농촌지역의 고용창출 효과 등 긍정적인 결과를 얻었다. 대표적인 예로 미국의 네브래스카 주의 경우, 해안에서 멀리 떨어져 있는 특성 상 높은 물류비용으로 인해 곡물 수출 경쟁력이 없었으나 바이오에탄올 생산 이후 농촌 고용이 증가하였다(Goto, 2012).

ASEAN의 경우, 바이오연료 의무혼합률과 정책을 통해 몇 가지 시사점을 다음과 같이 정리해 볼 수 있다. ASEAN은 바이오연 료 관련 기술적 제약이 많음에도 불구하고 미래의 기후변화 문제를 해결하기 위해 노력해 오고 있다. 현재까지 ASEAN은 바이오연료 정책을 위한 보조와 지원이 체계적으로 이루어지지 않고 있지만 각 국가와 지역적인 특성을 반영하여 제도를 시행해야 한다. 사례로, 필리핀의 경우 섬나라의 특성을 반영한 원료 작물 기반의 바이오연료 생산량을 예측하여 의무혼합률 정책을 펼쳐야 한다.

\subsection{1. 환경 문제와 R\&D 현황 및 제한요소}

미국의 RFS II에 따르면 구체적인 목질계 바이오연료를 정의하여 각 카테고리에서 전주기 배출량의 최소 목표치를 달성해야 한다. 또한, $\mathrm{EU}$ 의 RED에서는 2020년까지 $6 \%$ 의 GHG감축과 이에 따른 경작 시 이산화질소 배출 등 기후변화에 영향을 미칠 조건들의 구체적인 기준이 있다. RED II 에서는 2030 년까지 전기, 냉난방 및 운송 분야에서 소비되는 에너지로부터 $27 \%$ 의 재생 에너지 점유율을 달성하기 위한 일련의 정책 수단을 제안한다(EU Commission, 2018).

일반적으로 ASEAN 은 세계에서 GHG 배출량 감축 부분에서 중요한 역할을 하는데 해수면 상승 영향에 취약한 광대한 연안 지역과 수천 개의 섬이 ASEAN에 속해있기 때문이다 (IEA 2017). GHG 배출량 측면에서 본 태국의 1 인당 GDP는 세계 
평균보다 낮은 수준이지만 기후변화 문제와 관련하여 2015-2050년에 걸친 장기적인 GHG 감축목표를 세우는 등 적극적으로 정책을 시행하고 있다(APEC, 2015). 페루 리마(Lima)에서 개최된 COP 20에서 태국은 에너지 및 운송 분야의 BAU 수준에 서 2020 년 이전까지 GHG 배출량을 7-20\% 감축하는 공약을 발표하였다(APEC, 2015). 그러나 태국을 포함한 대부분의 ASEAN 국가는 재생 에너지 지원 정책 및 인센티브가 부족하며 이를 극복할 수 있는 방안을 찾는 것이 시급한 문제라고 할 수 있다. 따라서 미국과 브라질, 유럽연합과 같은 재생 에너지 개발 및 사용에서 이미 상당한 진전을 이룬 국가에서의 훌륭한 경제 관행을 채택함으로써 신속하게 발전할 수 있을 것으로 기대된다. 또한, 브라질과 같이 시장에서 더 많은 FFV 의 도입은 전체 운송 에너지 수요에서 바이오연료의 점유율을 증가시키는 데 도움이 될 수 있다. 그러나 1 세대 연료의 원료가 되는 식물들의 생산은 시간이 흐를 수록 감소하는 추세이며, 사례로 인도네시아에서 바이오연료 생산을 위한 1 세대 바이오매 스 생산은 2030년에는 10\%보다도 낮을 것으로 예측된다(IRENA, 2017a). 이를 위한 대책으로는 나머지 $90 \%$ 이상이 첨단 바이오연료로 보완되거나 1 차 바이오매스 생산을 위한 농지를 확대시키는 방법이 있다. 첨단 원료를 이용하여 바이오연료를 생산하는 경우에는 셀룰로오스 가수분해 및 열분해와 같은 기술을 발전하는 데 도움이 될 것이다. 따라서 정책지원과 세제혜 택, 기술한계점의 극복 등의 문제점등이 우선적으로 해결되어야 한다.

그림 4는 OECD에서 분류된 선진국 과 개발도상국의 재생에너지 투자율에 관하여 보여준다. 2016년까지 선진국의 투자가 약간 줄어들었음에도 불구하고 전반적으로 높은 비율을 보였으나 2017년에는 개발도상국 3개국인 브라질과 인도, 중국이 약 1436억 USD로 앞서게 되었다. 투자하고 있는 재생에너지의 비율(그림 5)을 보면 태양열에너지가 압도적인 1위를 차지하고 있으며 풍력에너지와 바이오연료가 그 뒤를 잇고 있다.

태양광 발전은 2016년 대비 2017년에 6\% 증가하여 약 47억 USD를, 풍력발전은 약 19억 USD를 최고치로 각각 기록하 였다. 바이오연료 분야의 경우, 17 억 USD로 약 $2 \%$ 증가하였다 (BNEF, 2018). UNEP에 따르면, 태양열과 풍력발전의 경우 기업의 연구 개발 비용이 절반을 차지하는 반면 바이오연료는 약 5 분의 4 를 차지하게 된다. 이러한 어려운 여건 하에 $2 \%$ 상승은 긍정적인 결과라고 해석 할 수 있다. 현재, 선진국 대비 개발도상국의 재생에너지 연구가 활발하지 않은 이유는 대체로 선진기술의 부재와 연구 비용의 부족에 있다. 따라서 이 문제를 해결한다면 바이오연료 분야에서의 연구가 확대될 것으로 기대된다.

\subsection{2. 에너지안보와 지속가능한 정책 시행}

IRENA 는 인도네시아 GDP가 2030년까지 $0.3 \%$ 에서 $1.3 \%$ 까지 오를 것으로 예상하고 있으나 이는 모두 에너지 분야에서만 적용한 경우이다(IRENA, 2017a). 재생에너지 관련 직업이 2030년에는 130만 군 이상이 되며 이는 2015년의 10만 1800직업군 에 비하여 상당히 높은 수치라 볼 수 있다(IRENA, 2017a). 또한, 이 분야의 고용 창출을 위한 농촌지역에서의 교육 확대를 통해 기술 교육 커리큘럼을 구축함으로써 현재의 재생에너지 관련 교육 부족 문제를 해결할 수 있다. ASEAN 경제의 에너지 집약도는 2025년까지 REmap에서 2005년 수준보다 약 30\% 가량 감소할 것으로 예측되며 이는 대체로 ASEAN의 에너지 집약도 개선 목표에 부합한다(IRENA, 2016). 바이오연료에 대한 지속 가능성 논의는 주로 직접 및 간접 토지 이용 변화와 관련된 GHG 배출에 초점을 두고 있다(Frank et al., 2013). 최근 생물 다양성과 서식지손실에 대한 바이오연료의 부정적인 영향에 대한 우려가 제기되었다. 그러나 결론적으로, REDD 뿐만 아니라 모든 토지 이용 변화와 같은 광범위한 정책과의 결합은 이후 생물 다양성 보전달성에 있어 정책의 전반적인 효과를 향상시키는 것으로 판단되었다(Frank et al., 2013). 각 정부는 지역 및 국제 에너지 협력 강화 및 에너지 수입원을 다양화하고 재생에너지 개발에 힘쓰는 등 에너지 안보를 향상하기 위해 노력해야 한다. 이에 주의해야 할 점으로 RFS와 RED를 시행하면서 공통 부분으로 2장과 3장에서도 확인할 수 있듯이 의무혼합률 계획을 높게 설정했다가 다시 하향 조정하는 사례가 있었다는 것이다. 그림 5 를 보면 인도네시아의 의무혼합률 목표와 국내에서의 실제 바이오연료 소비량의 차이를 파악 할 수 있다. 이를 통해 무리하여 계획을 세우기보다는 현실적으로 실현 가능한 목표를 세워야 한다는 것을 배울 수 있다.

그림 7과 8에서는 2013년부터 2040년까지 미국과 동남아시아 국가에서의 시대 별로 각각 바이오디젤과 바이오에탄올 의 공급 잠재력을 보여준다. 동남아시아의 바이오에탄올 수요는 전망 기간 동안 꾸준히 증가하고 있는데, 이는 수송 에너지 수요가 급격히 증가하고 잠재 공급이 여전히 낮은 상태이기 때문이다(APEC, 2016). 동남아에서 바이오에탄올 생산은 2030년부터 2040년까지 증가하는 수요를 충족시키지 못하는데 결과적으로 일부 국가는 해외 생산자로부터 추가 공급 물 량을 확보하거나 첨단 바이오에탄올 원료 공급원을 개발 및 배치해야 한다(APEC, 2016). 일부 국가에서 바이오연료 수요 를 늘리고 공급 가능한 잠재력을 활용하기 위해 기존 조치를 강화하고 보다 높은 혼합 목표를 설정하기 위해서는 정부 
지원이 필요할 것으로 판단된다.

\section{4. 결 론}

바이오연료는 더 이상 실험에서만 존재하는 연료가 아닌 현실에서 직접 쓰이고 있는 대체연료이다. 미국과 유럽연합은 각각 $\mathrm{RFS}$ 와 RED를 통해 바이오에너지를 비롯한 바이오연료에 관한 범 국가적 차원의 정책을 시행하고 있는 것을 고려할 때 ASEAN 역시 이 분야에서의 향후 적극적 정책수립이 필요하다. 또한, 연료다양화 개발과 기후변화 문제에 대응하기 위한 노력의 일환으 로, 각 정부는 바이오연료의 의무혼합률의 점진적 증가 목표를 설정함으로써 지속가능 정책을 실현할 수 있다. 향후 바이오연료 의 방향으로서 식용 자원에 포함되는 1 세대 바이오매스가 아닌 이를 대체할 수 있는 목질계 바이오매스와 미세조류를 활용한 기술의 연구가 계속해서 진행 되어야 할 것이다. 이를 위한 보조 정책과 세제혜택, 원료 공급의 원활함 등이 한 국가의 바이오연료 기술의 발전속도에 큰 영향을 미칠 것으로 판단된다.

이와 같이 바이오연료 활용도가 높은 미국과 브라질, 유럽의 상황을 살펴 본 결과, ASEAN에서의 활발한 바이오연료의 이용을 위해서는 우선적으로 각 나라의 바이오매스 자원 현황 파악이 중요하다. 또한 선진국의 재생에너지 수급 정책 등 효율적 인 경제 정책을 반영하여 이에 필요한 관련 법규를 제정해야 할 것으로 여겨진다. 